\title{
PHARMACOKINETIC PARAMETERS OF CIPROFLOXACIN IN BANGLADESHI VOLUNTEERS: A PRELIMINARY EVALUATION
}

\author{
REEFAT ZAMAN CHOWDHURY ${ }^{1}$, MD SAIFUL ISLAM ${ }^{2}$, MD SAYEDUR RAHMAN ${ }^{3}$ \\ ${ }^{1}$ Professor, Department of Pharmacology \& Therapeutics, Z H Sikder Women's Medical College, Dhaka, Bangladesh \\ ${ }^{2}$ Professor, Department of Clinical Pharmacy \& Pharmacology, University of Dhaka, Dhaka, Bangladesh \\ ${ }^{3}$ Associate Professor, Department of Pharmacology, Bangabandhu Sheikh Mujib Medical University, Dhaka, Bangladesh
}

\begin{abstract}
The present study has attempted to establish a High-performance liquid chromatography (HPLC) method to determine ciprofloxacin in plasma, in order to evaluate the bioavailability of ciprofloxacin. In this study, initially 8 (eight) Bangladeshi Bangalee healthy male volunteers and 7 (seven) Bangladeshi Tribal healthy male volunteers received $500 \mathrm{mg}$ tablet of pioneer brand of ciprofloxacin in oral route. Blood samples were collected at $0,30,60,120,180,360,540$ and 720 minutes after drug administration. After 1 week of washout period, same volunteers of two groups received $200 \mathrm{mg}$ injection of pioneer brand of ciprofloxacin in intravenous route. HPLC with ultraviolet detection was used to quantify plasma ciprofloxacin concentrations. In case of oral route, AUC $_{0-12 h,} \mathrm{C}_{\text {max }} \mathrm{T}_{\max }$ and $\mathrm{T}_{1 / 2}$ values for Bangladeshi Bangalee and Tribal healthy volunteers were $545.53 \pm 32.35$ \& 655.74 $\pm 16.57 \mu \mathrm{g} \mathrm{min} / \mathrm{mL}, 2.19 \pm 0.16 \& 2.49 \pm 0.20 \mu \mathrm{g} / \mathrm{mL}, 75.00 \pm 27.77 \& 94.29 \pm 32.07 \mathrm{~min}$ and $241.96 \pm 13.53 \& 242.02 \pm 19.88$ min respectively. In case of intravenous route, the AUC $C_{0-12 \mathrm{~h},} \mathrm{C}_{\max }, \mathrm{T}_{\max }$ and $\mathrm{T}_{1 / 2}$ values for Bangladeshi Bangalee and Tribal healthy volunteers were $344.07 \pm 29.31 \& 343.31 \pm 25.34 \mu \mathrm{g}$ $\mathrm{min} / \mathrm{mL}, 2.47 \pm 0.17 \& 2.46 \pm 0.18 \mu \mathrm{g} / \mathrm{mL}, 30.00 \pm 0.00 \& 30.0 \pm 0.0 \mathrm{~min}$ and $278.16 \pm 1.74 \& 272.74 \pm 4.42$ min respectively and the difference between these two groups of volunteers was not significant. The difference in $A \cup C_{0-12 h}, \mathrm{C}_{\max }, \mathrm{T}_{\max }$ and $\mathrm{T}_{1 / 2}$ values between these two groups of volunteers was significant. The mean percent absolute bioavailability in Bangladeshi Bangalee and Tribal healthy volunteers was $64.04 \pm 3.21$ and $76.81 \pm 6.71$ respectively. In conclusion, pharmacokinetic parameters of ciprofloxacin significantly varied among Bangladeshi Bangalee and Bangladeshi Tribal healthy volunteers indicating necessity of further study on population pharmacokinetic in these groups of people.
\end{abstract}

Keywords; Ciprofloxacin; Bangladeshi Bangalee; Bangladeshi Tribal; healthy volunteers; Pharmacokinetic parameters; Bioavailability

(Bangladesh J Physiol Pharmacol 2011;27(1\&2):1-8.)

\section{INTRODUCTION}

Bangladesh features different disease pattern than that of the developed countries because of its' socioeconomic and geographical difference. Infections are the main reason of morbidity and mortality, though recently burden of non-communicable diseases are increasing. Consequently, antimicrobials constitute a significant proportion of drug budget of Bangladesh..$^{1-5}$ In addition, emergence of resistance has worsened the situation. These issues jointly led to a position, where antimicrobials warrant immediate attention as the most important drug to watch in Bangladesh., ${ }^{2,6-7}$ Detail understanding about local, regional, and national antimicrobial susceptibility surveillance data is required in order to assist choice of appropriate agents. ${ }^{8}$ Though there are few studies on susceptibility pattern, however, very little is known about pharmacokinetic status of the Bangladeshi population regarding the antimicrobials.

Address for correspondence: Prof. Reefat Zaman Chowdhury, Department of Pharmacology \& Therapeutics, Z H Sikder Women's Medical College, Dhaka, Bangladesh; Email: reefatzaman@yahoo.com
Fluoroquinolones are extensively prescribed to treat different bacterial infections. ${ }^{9}$ Among the fluoroquinolones used in different level of health facilities of Bangladesh, ciprofloxacin is the most commonly consumed one. ${ }^{10}$ The commonly recommended oral dosage for adult patients is 250$500 \mathrm{mg}$ twice a day. Whenever taken orally, the drug usually recommended to be taken after 2 hours of meal. ${ }^{11}$ In order to explain the success and failure of antimicrobial therapy, there was effort to establish relationship between the in-vivo pharmacokinetic variability of ciprofloxacin at target site with the pharmacodynamics. ${ }^{12}$ Though, the pharmacokinetic parameters of ciprofloxacin in Bangladeshi population are not yet known. Therefore, the variability of response with ciprofloxacin is now only partially explained by the available sensitivity data, nevertheless detail understanding about it's pharmacokinetic parameters is required to explain that further. Inadequate information about the pharmacokinetic status of Bangladeshi people led to necessity of research to enable scientists to understand these issues. 
This is generally perceived that our knowledge of the pharmacokinetics and pharmacodynamics of antimicrobials has achieved a significant advance. Though there are different fluoroquinolones, they have their common pharmacokinetic and pharmacodynamic properties. Contrasting to the $\beta$-lactams and aminoglycosides, fluoroquinolones are not remaining limited to the blood. Fluoroquinolones penetrate mucosal tissues effectively to reach concentrations several times greater than serum, which has particular clinical relevance. Polymorphonuclear leucocytes and macrophages concentrate the fluoroquinolones to varying degrees, usually in excess of four times than that of the serum. The pharmacokinetic study shows that ciprofloxacin is bioequivalent when given in different formulations. ${ }^{13}$ Solubility improvement converts the medicines as potential candidate for bio-waiver of in vivo bioequivalence (BE) testing for oral dosage forms of ciprofloxacin. ${ }^{14}$

There are different methods to estimate ciprofloxacin in plasma, especially by HPLC 9, 15-16, however, the initial challenge was to establish a suitable method to estimate plasma ciprofloxacin in laboratories of Bangladesh. Therefore, the aim of this study was to establish a method of estimation of ciprofloxacin in plasma as well as to get preliminary idea about the pharmacokinetic behaviour of Bangladeshi healthy volunteers of two different ethnic groups.

\section{MATERIALS AND METHODS}

\section{Subject population}

The present study was conducted in two ethnic groups of Bangladeshi healthy volunteers e.g., Bangalee and Tribal. The family and anthropometric history was considered for confirmation of categorization. This study included 8 (eight) Bangladeshi Bangalee male healthy volunteers, aged 23-25 years (23.88 \pm 0.83 years), weighing between $50-60 \mathrm{~kg}(55.88 \pm 3.44 \mathrm{~kg})$ \& within $15 \%$ of the ideal bodyweight and 7 (seven) Bangladeshi Tribal male healthy volunteers, aged 23-25 years (24.14 \pm 0.69 years), weighing between $50-60 \mathrm{~kg}$ $(54.14 \pm 3.72 \mathrm{~kg}) \quad \&$ within $15 \%$ of the ideal bodyweight. Volunteers were screened to ensure that they have no cardiac, renal, hepatic, hematological, neurological, gastrointestinal and pulmonary disorders and allergy to ciprofloxacin. The volunteers were requested to stay away from any medication for two weeks prior to the study and up to its completion. Moreover, they were requested not to take any beverages like alcohol, coffee and tea in $48 \mathrm{~h}$ prior to first dose and until the collection of last blood sample. ${ }^{17}$

\section{Medicines}

Commercially available pioneer brand of ciprofloxacin $500 \mathrm{mg}$ tablets and $200 \mathrm{mg}$ injections were used.

\section{Medicine administration schedule}

This study was conducted in an open label design with one-week washout period between oral and intravenous doses. At the time of study, the volunteers were exclusively hospitalized at Z H Sikder Women's Medical College \& Hospital, Dhaka, Bangladesh. Initially, all volunteers received oral dose of $500 \mathrm{mg}$ ciprofloxacin tablet. After one-week wash period, the same volunteers received intravenous dose of $200 \mathrm{mg}$ ciprofloxacin. The volunteers were monitored by principal researcher (an experienced physician) to detect adverse effects (if any) during the study.

\section{Blood sample collection}

For collection of blood samples, a catheter in situ was placed in one arm by the researcher with all aseptic precaution. The catheter was removed immediately if phlebitis develops, otherwise normally after the study period. Seven blood samples ( $3 \mathrm{ml}$ at each occasion) were obtained at $0,30,60,120,180,360,540$ and 720 minutes after drug administration and placed in sterile tubes with $100 \mu \mathrm{L}$ of $10 \%$ EDTA solution. Immediately after each blood collection, the samples were centrifuged at $3000 \times \mathrm{g}$ for $15 \mathrm{~min}$ and plasma was then separated and stored at $-70^{\circ} \mathrm{C}$. The stored samples were then studied by HPLC in appropriate method. ${ }^{14-16}$

\section{Sample analysis}

Ciprofloxacin plasma concentrations were measured by HPLC. Specificity, linearity, lower limit of quantification (LLOQ), inter-day and intra-day precision and accuracy as well as absolute recovery and stability of ciprofloxacin was evaluated.

\section{Chromatographic analysis}

Ciprofloxacin analysis was performed using previously adapted and validated methods. ${ }^{18-20}$

\section{Chromatographic Condition}

HPLC: Alliance HPLC, Origin: Waters USA (Separation Module, Model: Waters 2695; Detector, Model: Waters 2487 and Empower software)

Column: Symmetry C18 $(2.5 \mathrm{~cm} \times 4.6 \mathrm{~mm})$, Waters-USA

Flow rate: $1.30 \mathrm{~mL} / \mathrm{min}$

Run Time: $10 \mathrm{~min}$

Column Temperature: Ambient

Detector: UV detector

Test wave length: $278 \mathrm{~nm}$

Cell temperature: $40^{\circ} \mathrm{C}$

Injection Volume: $50 \mu \mathrm{L}$

\section{Reagents}

Sodium Dihydrogen Phosphate Dihydrate $(M W=156.01)$ - Analytical Reagent Grade Acetonitrile - HPLC Grade. 
Preparation of $0.025 \mathrm{M}$ phosphoric acid buffer, $\mathrm{pH}=\mathbf{4 . 0}$

$1.5 \mathrm{ml}$ of conc. $\mathrm{H} 3 \mathrm{PO} 4$ was taken in $1.0 \mathrm{~L}$ volumetric flask and then diluted with $\mathrm{H} 2 \mathrm{O}$ pH was adjusted at 4.0 with $5 \mathrm{M} \mathrm{NaOH}$ solution

\section{Preparation of Mobile Phase $80: 20$ \\ $0.025 \mathrm{M}$ phosphoric acid buffer: Acetonitrile $=$}

\section{Preparation of Diluent for Stock solution and Working Standard \\ Water: Acetonitrile $=95: 5$}

\section{Preparation of stock solution}

$110.90 \mathrm{mg}$ of Ciprofloxacin $\mathrm{Hcl}(100 \mathrm{mg}$ of Ciprofloxacin) was taken in $100 \mathrm{ml}$ volumetric flask. Then that was dissolved and diluted with $\mathrm{H}_{2} \mathrm{O}$

Preparation of Working Standard from Stock Solution (Concentration: $1000 \mu \mathrm{g} / \mathrm{mL}$ )

Working Standard $1 \mu \mathrm{g} / \mathrm{mL}: 0.1 \mathrm{~mL}$ of stock solution was taken in $100 \mathrm{~mL}$ of volumetric flask, diluted and then volume increased up to mark with diluent.

Working Standard $10 \mu \mathrm{g} / \mathrm{mL}: 1.0 \mathrm{~mL}$ of stock solution was taken in $100 \mathrm{~mL}$ of volumetric flask, diluted and then volume increased up to mark with diluent.

Working Standard $100 \mu \mathrm{g} / \mathrm{mL}: 10.0 \mathrm{~mL}$ of stock solution was taken in $100 \mathrm{~mL}$ of volumetric flask, diluted and then volume was increased up to mark with diluent.

\section{Preparation of Lomefloxacin Solution}

$107 \mathrm{mg}$ of Lomefloxacin (equivalent to $100 \mathrm{mg}$ of Lomefloxacin) was dissolved in $100 \mathrm{~mL}$ volumetric flask, diluted and later volume increased up to the mark with Methanol $(1000 \mu \mathrm{g} / \mathrm{mL}) .10 \mathrm{~mL}$ of this solution was taken in $100 \mathrm{~mL}$ volumetric flask and volume increased up to mark with methanol $(100 \mu \mathrm{g} / \mathrm{mL})$. Then $0.15 \mathrm{~mL}$ of this solution was taken and $0.85 \mathrm{ml}$ of methanol was added to make $1 \mathrm{~mL}$ of Final solution $(15 \mu \mathrm{g} / \mathrm{mL})$.

\section{Preparation of sample Solution:}

$0.1 \mathrm{~mL}$ of plasma was mixed with $0.90 \mathrm{ml}$ of $\mathrm{MeOH}$ to make $1.0 \mathrm{~mL}$ of sample solution.

Injection Step

Step 1: $1 \mathrm{~mL}$ of drug free plasma $+9 \mathrm{~mL} \mathrm{MeOH}=$ $10 \mathrm{~mL}$ solution as a blank

Step 2: $1 \mathrm{~mL}$ of drug free plasma $+1 \mathrm{~mL}$ Lomefloxacin $(15 \mu \mathrm{g} / \mathrm{mL})+8 \mathrm{ml} \mathrm{MeOH}=10 \mathrm{~mL}$ solution

Step 3: $1 \mathrm{~mL}$ of drug free plasma $+1 \mathrm{~mL}$ of Ciprofloxacin $(20 \mu \mathrm{g} / \mathrm{mL})+1 \mathrm{ml}$ Lomefloxacin $(15 \mu \mathrm{g} / \mathrm{mL})+7 \mathrm{~mL} \mathrm{MeOH}=10 \mathrm{~mL}$ solution

Step 4: Working Standard

Step 5: Samples

\section{Specificity}

The specificity of the method was determined by comparing the chromatograms obtained from the samples containing ciprofloxacin and internal standard with those obtained from blank samples.

\section{Calibration and validation}

Standard Ciprofloxacin samples were prepared in control plasma using standard stock solutions of Ciprofloxacin (1.00, 10.00 and $100.00 \mu \mathrm{g} / \mathrm{mL}$ ). The overall coefficient of correlation between fluorescence and standard drug concentrations was $0.99+0.009$ and the standard curve obtained was linear and followed Beer's law from 0.07 to $1.15 \mu \mathrm{g} / \mathrm{mL}$. The overall recovery of Ciprofloxacin from plasma standard solutions was $98.85 \pm 1.86$ per cent with a range of 98.85 to 100.41 per cent. The interday coefficient of variation of the recovery from standards in the above mentioned range was $2.21 \pm 1.83$ per cent.

\section{Pharmacokinetic and data analysis}

Maximum observed plasma concentration $\left(C_{\max }\right)$ and time taken to reach it $\left(T_{\max }\right)$ were obtained from drug concentration vs. time curves. The areas under the ciprofloxacin concentrations vs. time curves from 0-12 hours $\left(\mathrm{AUC}_{0-12 \mathrm{~h}}\right)$ were calculated using the trapezoidal method. $T_{1 / 2}$ was calculated through determining $k_{e l}$ by utilizing the intravenous data. $\mathrm{C}_{\max }$ and $\mathrm{AUC}_{0-12 \mathrm{~h}}$ data were analyzed statistically using parametric test, i.e., one-way ANOVA. A customized non-compartmental pharmacokinetics data analysis Excel template was developed to calculate and analyze the parameters.

\section{Ethical clearance}

The protocol of this study was approved by the National Research Ethics Committee of Bangladesh Medical Research Council. Informed written consent was obtained from all participants after explaining the nature, risk and benefits of the study to them.

\section{STATISTICAL ANALYSIS:}

Data were analyzed by using SPSS soft-ware version 18. The values for quantitative data were expressed as mean, mean $\pm S D$, while that of qualitative data were presented as percent.

\section{RESULTS}

All volunteers completed the study without any event, which was ascertained by thorough medical examination after study completion.

HPLC was sensitive in quantifying ciprofloxacin in plasma (limit of quantification $=0.1 \mu \mathrm{g} / \mathrm{mL}$; $\left.\mathrm{R}^{2}=0.9996\right)$. Fig 1 shows the calibration curve for the HPLC method. 

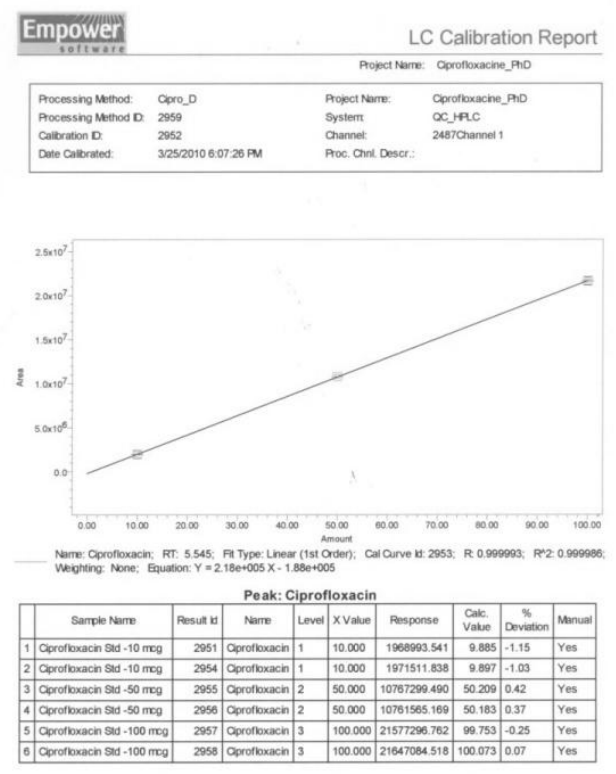

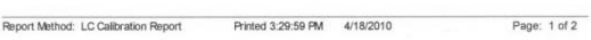

\section{Figure 1}

Presentation of result with adjustment: In order to minimize the effect of variation in weight of the volunteers, the obtained actual plasma concentration was adjusted as per mg of ciprofloxacin per $\mathrm{kg}$ bodyweight and then used for calculation of different pharmacokinetic parameters. Therefore, the $A U C_{0-8 h}$ and $C_{\max }$ were calculated with two values, one with the original plasma concentration of amoxicillin detected in HPLC and the other was with value obtained after adjustment. The Mean Percent Absolute Bioavailability was calculated by using the adjusted values.

Table I shows that there was no significant ( $p>0.05$ ) difference between the subjects of two study groups in respect of different parameters.

Table II shows that in case of oral route, the AUC $_{0-12 \mathrm{~h}}$ for Bangladeshi Bangalee and Tribal healthy volunteers were $545.53 \pm 32.35 \& 655.74 \pm 16.57 \mu \mathrm{g}$ $\mathrm{min} / \mathrm{mL}$ respectively and the difference was statistically significant $(p<0.05)$. The $C_{\max }$ values for Bangladeshi Bangalee and Tribal healthy volunteers were $2.19 \pm$ $0.16 \& 2.49 \pm 0.20 \mu \mathrm{g} / \mathrm{mL}$ respectively and the difference was statistically significant $(p<0.05)$. The $\mathrm{T}_{\max }$ for Bangladeshi Bangalee and Tribal healthy volunteers were $75.00 \pm 27.77 \& 94.29 \pm 32.07 \mathrm{~min}$ and the difference was not statistically significant ( $p>0.05$ ). The $T_{1 / 2}$ for Bangladeshi Bangalee and Tribal healthy volunteers were $241.96 \pm 13.53 \& 242.02 \pm$ 19.88 min respectively and the difference was not statistically significant $(p>0.05)$. The $C_{\text {trough }}$ values for Bangladeshi Bangalee and Tribal healthy volunteers were $0.11 \pm 0.01 \& 0.12 \pm 0.01$ min respectively and the difference was not statistically significant ( $p>0.05)$.

Table III shows that in case of intravenous route, the $\mathrm{AUC}_{0-12 \mathrm{~h}}$ for Bangladeshi Bangalee and Tribal healthy volunteers were $344.07 \pm 29.31 \& 343.31 \pm 25.34 \mu \mathrm{g}$ $\mathrm{min} / \mathrm{mL}$ respectively and the difference was not statistically significant. The $\mathrm{C}_{\max }$ values for Bangladeshi Bangalee

Table I

Age, weight, height, Body Mass Index (BMI), serum creatinine, serum ALT and Prothrombin time of the Bangladeshi Bangalee and Tribal healthy volunteers

\begin{tabular}{|c|c|c|c|c|}
\hline & $\begin{array}{l}\text { Bangalee } \\
(n=8) \\
\text { Mean } \pm \text { SD }\end{array}$ & $\begin{array}{l}\text { Tribal } \\
(n=7) \\
\text { Mean } \pm \text { SD }\end{array}$ & $\mathbf{t}$ & P value \\
\hline $\begin{array}{l}\text { Age } \\
\text { (years) }\end{array}$ & $\begin{array}{l}23.88 \pm 0.83 \\
(23.00-25.00)\end{array}$ & $\begin{array}{l}24.14 \pm 0.69 \\
(23.00-25.00)\end{array}$ & 0.68 & $>0.05$ \\
\hline $\begin{array}{l}\text { Weight } \\
(\mathrm{kg})\end{array}$ & $\begin{array}{l}55.88 \pm 3.44 \\
(51.00-60.00)\end{array}$ & $\begin{array}{l}54.14 \pm 3.72 \\
(51.00-60.00)\end{array}$ & 0.93 & $>0.05$ \\
\hline $\begin{array}{l}\text { Height } \\
(\mathrm{cm})\end{array}$ & $\begin{array}{l}165.00 \pm 4.00 \\
(160.00-172.00)\end{array}$ & $\begin{array}{l}164.00 \pm 3.00 \\
(160.00-170.00)\end{array}$ & 0.69 & $>0.05$ \\
\hline Body Mass Index (BMI) & $\begin{array}{l}20.50 \pm 1.22 \\
(18.87-22.58)\end{array}$ & $\begin{array}{l}20.15 \pm 1.70 \\
(18.59-23.15)\end{array}$ & 0.45 & $>0.05$ \\
\hline Serum Creatinine (mg/dL) & $\begin{array}{l}0.76 \pm 0.09 \\
(0.60-0.80)\end{array}$ & $\begin{array}{l}0.74 \pm 0.08 \\
(0.60-0.80)\end{array}$ & 0.45 & $>0.05$ \\
\hline $\begin{array}{l}\text { Serum ALT } \\
(U / L)\end{array}$ & $\begin{array}{l}35.88 \pm 3.94 \\
(30.00-45.00)\end{array}$ & $\begin{array}{l}35.29 \pm 3.86 \\
(30.00-40.00)\end{array}$ & 0.29 & $>0.05$ \\
\hline Prothrombin Time (seconds) & $\begin{array}{l}9.88 \pm 0.83 \\
(9.00-12.00)\end{array}$ & $\begin{array}{l}10.29 \pm 0.49 \\
(10.00-12.00)\end{array}$ & 1.18 & $>0.05$ \\
\hline
\end{tabular}


and Tribal healthy volunteers were $2.47 \pm 0.17 \& 2.46 \pm$ $0.18 \mu \mathrm{g} / \mathrm{mL}$ respectively and the difference was not statistically significant. The $\mathrm{T}_{\max }$ for Bangladeshi Bangalee and Tribal healthy volunteers were $30.00 \pm 0.00 \&$ $30.0 \pm 0.0 \mathrm{~min}$ and the difference was not statistically significant. The $T_{1 / 2}$ for Bangladeshi Bangalee and Tribal healthy volunteers were $278.16 \pm 1.74 \& 272.74 \pm 4.42 \mathrm{~min}$ respectively and the difference was statistically significant $(p<0.05)$. The $C_{\text {trough }}$ values for Bangladeshi Bangalee and Tribal healthy volunteers were $0.07 \pm 0.03 \& 0.02 \pm 0.01$ min respectively and the difference was statistically significant $(p<0.05)$.

Table II

Pharmacokinetic parameters following oral administration of 500 mg ciprofloxacin tablet in Bangladeshi Bangalee and Tribal healthy volunteers

\begin{tabular}{|c|c|c|c|c|c|}
\hline $\begin{array}{l}\text { Pharmacokinetic } \\
\text { parameters }\end{array}$ & $\begin{array}{l}\text { Bangalee }(n=8) \\
\text { Mean } \pm \text { SD }\end{array}$ & $\begin{array}{l}\text { Tribal }(n=7) \\
\text { Mean } \pm \text { SD }\end{array}$ & ANOVA & $\mathbf{t}$ & P value \\
\hline $\begin{array}{l}A_{U C C_{0-12 h}} \\
(\mu \mathrm{g} \mathrm{min} / \mathrm{mL})\end{array}$ & $\begin{array}{l}545.53 \pm 32.35 \\
(498.09-586.91)\end{array}$ & $\begin{array}{l}655.74 \pm 16.57 \\
(637.71-683.09)\end{array}$ & 65.71 & 2.34 & $<0.05$ \\
\hline $\begin{array}{l}C_{\max } \\
(\mu \mathrm{g} / \mathrm{mL})\end{array}$ & $\begin{array}{l}2.19 \pm 0.16 \\
(2.00-2.41)\end{array}$ & $\begin{array}{l}2.49 \pm 0.20 \\
(2.27-2.77)\end{array}$ & 10.89 & 3.25 & $<0.05$ \\
\hline $\begin{array}{l}\mathrm{T}_{\max } \\
(\min )\end{array}$ & $\begin{array}{l}75.00 \pm 27.77 \\
(60.00-120.00)\end{array}$ & $\begin{array}{l}94.29 \pm 32.07 \\
(60.00-120.00)\end{array}$ & 0.00 & 1.24 & $>0.05$ \\
\hline $\begin{array}{l}\mathrm{T}_{1 / 2} \\
\text { (min) }\end{array}$ & $\begin{array}{l}241.96 \pm 13.53 \\
(222.88-258.29)\end{array}$ & $\begin{array}{l}242.02 \pm 19.88 \\
(209.53-262.83)\end{array}$ & 0.00 & 0.01 & $>0.05$ \\
\hline $\begin{array}{l}C_{\text {trough }} \\
(\mu \mathrm{g} / \mathrm{mL})\end{array}$ & $\begin{array}{l}0.11 \pm 0.01 \\
(0.10-0.12)\end{array}$ & $\begin{array}{l}0.12 \pm 0.01 \\
(0.10-0.13)\end{array}$ & 0.75 & 0.83 & $>0.05$ \\
\hline $\begin{array}{l}\text { AUC }_{0-12 \mathrm{~h}} \\
(\mu \mathrm{g} \mathrm{min} / \mathrm{mL} \text { per } \mathrm{mg} / \mathrm{kg})\end{array}$ & $\begin{array}{l}61.54 \pm 3.66 \\
(57.37-66.91)\end{array}$ & $\begin{array}{l}71.04 \pm 5.83 \\
(65.38-81.97)\end{array}$ & 14.67 & 3.72 & $<0.05$ \\
\hline $\begin{array}{l}C_{\max } \\
(\mu g / m L \text { per } \mathrm{mg} / \mathrm{kg})\end{array}$ & $\begin{array}{l}0.25 \pm 0.02 \\
(0.22-0.27)\end{array}$ & $\begin{array}{l}0.27 \pm 0.03 \\
(0.23-0.32)\end{array}$ & 2.93 & 1.64 & $>0.05$ \\
\hline
\end{tabular}

With adjusted value means the original values obtained was later adjusted for per $\mathrm{mg}$ of ciprofloxacin/kg bodyweight

Table III

Pharmacokinetic parameters following intravenous administration of $200 \mathrm{mg}$ ciprofloxacin in Bangladeshi Bangalee and Tribal healthy volunteers

\begin{tabular}{|c|c|c|c|c|c|c|}
\hline $\begin{array}{l}\text { Pharmacokinetic } \\
\text { parameters }\end{array}$ & Unit & $\begin{array}{l}\text { Bangalee }(n=8) \\
\text { Mean } \pm \text { SD }\end{array}$ & $\begin{array}{l}\text { Tribal }(n=7) \\
\text { Mean } \pm \text { SD }\end{array}$ & ANOVA & $\mathbf{t}$ & P value \\
\hline $\mathrm{AUC}_{0-12 \mathrm{~h}}$ & $(\mu \mathrm{g} \min / \mathrm{mL})$ & $\begin{array}{l}344.07 \pm 29.31 \\
(299.31-373.79)\end{array}$ & $\begin{array}{l}343.31 \pm 25.34 \\
(312.08-382.43)\end{array}$ & 12.28 & 0.02 & $>0.05$ \\
\hline $\mathrm{C}_{\max }$ & $(\mu \mathrm{g} / \mathrm{mL})$ & $\begin{array}{l}2.47 \pm 0.17 \\
(2.22-2.68)\end{array}$ & $\begin{array}{l}2.46 \pm 0.18 \\
(2.21-2.74)\end{array}$ & 4.08 & 0.17 & $>0.05$ \\
\hline $\mathrm{T}_{\max }$ & $(\min )$ & $30.00 \pm 0.00$ & $30.00 \pm 0.00$ & 0.00 & 0.00 & NA \\
\hline $\mathrm{T}_{1 / 2}$ & $(\min )$ & $\begin{array}{l}278.16 \pm 1.74 \\
(275.63-280.68)\end{array}$ & $\begin{array}{l}272.74 \pm 4.42 \\
(267.02-277.97)\end{array}$ & 12.83 & 3.05 & $<0.05$ \\
\hline $\mathrm{C}_{\text {trough }}$ & $(\mu \mathrm{g} / \mathrm{mL})$ & $\begin{array}{l}0.07 \pm 0.03 \\
(0.03-0.10)\end{array}$ & $\begin{array}{l}0.02 \pm 0.01 \\
(0.01-0.03)\end{array}$ & 15.92 & 4.23 & $<0.05$ \\
\hline $\mathrm{AUC}_{0-12 \mathrm{~h}}$ & $\begin{array}{l}(\mu \mathrm{g} \mathrm{min} / \mathrm{mL} \\
\text { per } \mathrm{mg} / \mathrm{kg})\end{array}$ & $\begin{array}{l}96.16 \pm 4.80 \\
(89.79-103.90)\end{array}$ & $\begin{array}{l}92.57 \pm 2.47 \\
(87.98-95.61)\end{array}$ & 3.16 & 1.85 & $>0.05$ \\
\hline $\mathrm{C}_{\max }$ & $\begin{array}{l}(\mu \mathrm{g} / \mathrm{mL} \text { per } \\
\mathrm{mg} / \mathrm{kg})\end{array}$ & $\begin{array}{l}0.69 \pm 0.03 \\
(0.67-0.74)\end{array}$ & $\begin{array}{l}0.66 \pm 0.01 \\
(0.64-0.69)\end{array}$ & 6.47 & 2.66 & $<0.05$ \\
\hline
\end{tabular}

With adjusted value means the original values obtained was later adjusted for per $\mathrm{mg}$ of ciprofloxacin/kg bodyweight 
Table IV

Mean Percent Absolute Bioavailability (MPAB) of ciprofloxacin in Bangladeshi Bangalee and Tribal healthy volunteers

\begin{tabular}{|c|c|c|c|c|c|c|c|c|c|}
\hline & \multicolumn{3}{|c|}{$\begin{array}{l}\text { Bangalee } \\
n=8\end{array}$} & \multicolumn{3}{|l|}{$\begin{array}{l}\text { Tribal } \\
n=7\end{array}$} & \multirow[t]{2}{*}{ ANOVA } & \multirow[t]{2}{*}{ t value } & \multirow[t]{2}{*}{ p value } \\
\hline & Oral & IV & MPAB & Oral & IV & MPAB & & & \\
\hline Subject 1 & 60.47 & 89.79 & 67.35 & 65.53 & 95.61 & 68.54 & \multirow{10}{*}{6.65} & \multirow{10}{*}{4.59} & \multirow{10}{*}{$<0.01$} \\
\hline Subject 2 & 60.96 & 89.79 & 67.89 & 65.38 & 93.81 & 69.70 & & & \\
\hline Subject 3 & 62.35 & 97.91 & 63.69 & 81.97 & 93.62 & 87.55 & & & \\
\hline Subject 4 & 57.37 & 95.08 & 60.34 & 71.67 & 91.34 & 78.47 & & & \\
\hline Subject 5 & 57.68 & 97.18 & 59.35 & 73.97 & 93.80 & 78.86 & & & \\
\hline Subject 6 & 66.91 & 100.03 & 66.89 & 71.31 & 87.98 & 81.05 & & & \\
\hline Subject 7 & 66.76 & 103.90 & 64.26 & 67.47 & 91.82 & 73.48 & & & \\
\hline Subject 8 & 59.77 & 95.58 & 62.54 & & & & & & \\
\hline Mean & 61.54 & 96.16 & 64.04 & 71.04 & 92.57 & 76.81 & & & \\
\hline SD & 3.66 & 4.80 & 3.21 & 5.83 & 2.47 & 6.71 & & & \\
\hline
\end{tabular}

Calculated on the basis of adjusted AUC from plasma concentrations obtained after oral (500mg) and intravenous (200mg) administration of ciprofloxacin and expressed as per $\mathrm{mg}$ ciprofloxacin/kg bodyweight

Table IV shows that the Mean Percent Absolute Bioavailability in case of Bangladeshi Bangalee and Bangladeshi Tribal healthy volunteers was $64.04 \pm 3.21$ and $76.81 \pm 6.71$ respectively. The difference between these two values were highly significant $(p<0.01)$.

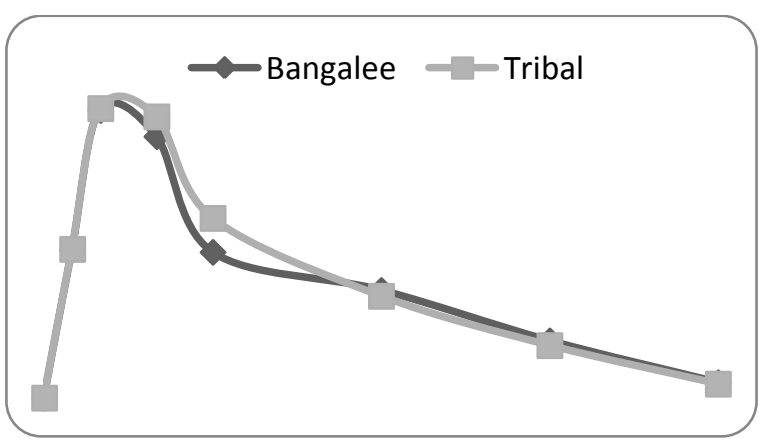

Figure 2: Time concentration curve obtained by plotting the mean plasma concentrations of ciprofloxacin estimated at different point of time (in oral route)

Figure $\mathbf{2}$ showing the time concentration curves obtained in the oral route. There are difference in the shape, slope and peak between the curves of Bangladeshi Banglaee and Tribal healthy volunteers. Difference is particularly observed in the mean concentrations obtained at 120, 180 and 230 minutes.

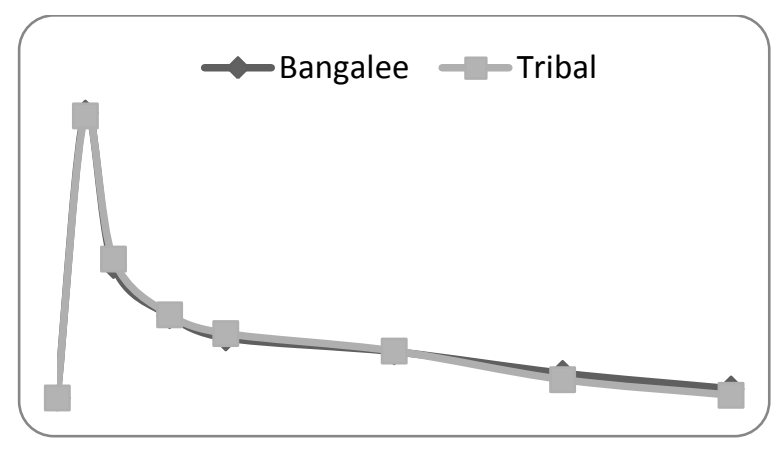

Figure 3: Time concentration curve obtained by plotting the mean plasma concentrations of ciprofloxacin estimated at different point of time (in intravenous route)

Figure 3 showing the time concentration curves obtained in the intravenous route. The curves reflect no difference in the shape and slope between the curves of Bangladeshi Banglaee and Tribal healthy volunteers. The $\mathrm{C}_{\max }$ is calculated by backward extrapolation of data up to 0 minute. The $C_{\max }$ in case of Banglaee and Tribal derived through extrapolation is 2.46 and $2.47 \mu \mathrm{g} / \mathrm{mL}$ respectively. 


\section{DISCUSSION}

Pharmacokinetic parameters of ciprofloxacin have been investigated at different doses of 250, 500, 750 and $1000 \mathrm{mg}^{19-22}$ Previous studies using chromatography have reported $\mathrm{C}_{\max }$ values of $2.18 \mu \mathrm{g} / \mathrm{mL}$ after oral administration of $500 \mathrm{mg}$ ciprofloxacin, ${ }^{13}$ and $1.5 \mu \mathrm{g} / \mathrm{mL}$ after $250 \mathrm{mg}$ ciprofloxacin. ${ }^{23}$ The $\mathrm{C}_{\max }$ observed in the present study after oral administration was modestly higher in case of Tribal and lower in case of Bangalee Bangladeshi in relation to the findings of the previous studies probably due to the dissimilarity in the population studied. Regarding intravenous route, one study ${ }^{16}$ has provided idea about the $\mathrm{AUC}_{0-12 \mathrm{~h}}$ and $\mathrm{C}_{\text {max., }}$ which are in cystic fibrosis patients and were $48.3 \mu \mathrm{g} \mathrm{h} / \mathrm{mL}$ and $2.9 \mu \mathrm{g} / \mathrm{mL}$ respectively.

The $A U C_{0-12 h}$ obtained in the present study for intravenous route both in case of Tribal and Banglaee was very low in comparison to the result observed by Montgomery et al 2001. ${ }^{16}$ The $\mathrm{AUC}_{0-12 \mathrm{~h}}$ obtained in the present study for oral route in case of Tribal was comparable to the findings of previous study, ${ }^{13}$ although the values for Bangalee were low.

Nevertheless, the $T_{\max }$ observed in the present study was parallel to the values revealed by previous researcher ${ }^{13}$ using same dose but that is different with findings with another study. ${ }^{23}$ However, the similarity in these findings reiterating the fact that different doses of the same drug have no influence on $\mathrm{T}_{\max }$ values.

For $\mathrm{T}_{1 / 2}$ values, different studies revealed a range of 2.9 hours to 5.37 hours with a mean of 100 minutes ${ }^{21-24}$ and the present study finding is similar to those observations.

The Mean Percent Absolute Bioavailability obtained in both Bangalee and Tribal volunteers in the present study appears to be lower than the previous report. ${ }^{25}$

In order to explain the significant difference observed in the present study, different meta-analysis and reviews were considered. Meta-analysis and reviews revealed that metabolism of different drugs has little association with CYP2C19 genotype. ${ }^{26}$ Study also suggests that the dose can be increased in populations with high frequencies of HomEMs or HetEMs. ${ }^{27}$

The pharmacokinetic parameters of amoxicillin in ethnically different Bangladeshi populations were revealed in a previous study, which was similar to the findings of the present study reiterating the necessity of further study with this focus. ${ }^{28}$ The pharmacokinetic parameters of orally administered ciprofloxacin tablet are well understood as a result of series of studies. ${ }^{29-33}$ In general, ciprofloxacin tablets dissolve rapidly in the gastrointestinal tract and are absorbed in the duodenum and jejunum. Following oral dosing, the bioavailability of ciprofloxacin is between $70 \%$ and $80 \%$. $^{34}$
The revealed significant difference between two groups of Bangladeshi healthy volunteers is really an interesting finding, which require further exploration with especial emphasis into genetic correlation. Further exploration might help to develop a population pharmacokinetic model, ${ }^{35}$ which will enable the researcher to suggest prescriber regarding optimum dosage calculation at an individual level applicable for Bangladeshi population. This type of difference in pharmacokinetic properties of Bangladeshi healthy volunteers needs to be correlated with therapeutic outcome as well.

\section{ACKNOWLEDGMENTS}

The principal researcher received grant from Ministry of Science \& Information Technology of the Government of Peoples Republic of Bangladesh. The principal author extends thank to Mr Anwar Hossain for his support in the work.

\section{REFERENCES}

1. Islam MS, Rahman MS, Misbahuddin M. Impact of 'Prescription Audit \& Feedback' on Pattern of Prophylactic Antimicrobials in Caesarean Section: a Cost Reduction Perspective. Bangladesh J Physiol Pharmacol 2007: 23: 1-9.

2. Rahman MS, Akhter N, Haque MZ, Begum M, Chowdhury FA, Karim A, Khan IA. Prescribing pattern of Antimicrobials at different level of health care services and the impact of interventions. Final Report submitted to Bangladesh Medical Research Council; 2001.

3. Chowdhury AK, Rahman MS, Faroque AB, Hasan GA, Raihan SZ. Excessive use of avoidable therapeutic injections in the upazilla health complexes of Bangladesh. Mymensingh Med J. 2008: 17(2 Suppl): S59-64.

4. Rahman MS, Khan IA, Chowdhury S, Islam AMZ, Sultana R, Hoque MZ, Akhter N. A Baseline Survey on the Use of Drugs at Private Practitioner Level in Bangladesh. Bangladesh J Physiol Pharmacol 1998: 14(2): 47-50.

5. Roda RP, Bagán JV, Bielsa JMS, Pastor EC. Antibiotic use in dental practice. A review. Med Oral Patol Oral Cir Bucal 2007; 12:E186-92.)

6. Hasan CM. Drug situation in Bangladesh. Paper presented by Director, Drug Administration in a Workshop on Rational Drug Use. DGHS, Dhaka. 1996.

7. Anderson S. Bangladesh: The use of drugs. Dan. Med. Bull.1984; 31: 31.

8. Jones RN, Pfaller MA, Doern GV, Erwin ME, Hollis RJ. Antimicrobial activity and spectrum investigation of eight broad-spectrum beta-lactam drugs: a 1997 surveillance trial in 102 medical centers in the United States. Cefepime Study Group. Diag Microbiol Infect Dis. 1998; 30: 215-28.

9. Lubasch A, Keller I, Borner K, Koeppe P, Lode H. Comparative Pharmacokinetics of Ciprofloxacin, Gatifloxacin, Grepafloxacin, Levofloxacin, Trovafloxacin, and Moxifloxacin after Single Oral Administration in Healthy. Antimicrob Agents Chemother 2000; 44: 2600-03.

10. International Medical Statistics (IMS). Switzerland 2009; 1st Quarter: Therapeutic class, Summary table 1, p.1.

11. McEvoy GK [Editor]. Ciprofloxacin. In, AHFS Drug Information 1999. American Society of Health System Pharmacists; Bethesda, MD 20814, USA 1999: pp. 670-84. 
12. Delacher $S$, Derendorf $H$, Hollenstein $U$, Brunner $M$, Joukhadar C, Hofmann S, Georgogopoulos A, Eichler HG, Muller M. A combined in-vivo pharmacokinetic in-vitro pharmacodynamic approach to stimulate target site pharmacodymaics of antibiotics in humans. J Antimicrob Chemother 2000; 46: 733-39.

13. Shah $A$, Liu M, Vaughan D, Heller AH. Oral bioequivalence of three ciprofloxacin formulations following single-dose administration: $500 \mathrm{mg}$ tablet compared with $500 \mathrm{mg} / 10 \mathrm{~mL}$ or $500 \mathrm{mg} / 5 \mathrm{~mL}$ suspension and the effect of food on the absorption of ciprofloxacin oral suspension. J Antimicrob Chemother 1999; 43: 49-54.],

14. Breda SA, Jimenez-Kairuz AF, Manzo RH, Olivera ME. Solubility behavior and biopharmaceutical classification of novel highsolubility ciprofloxacin and norfloxacin pharmaceutical derivatives. Int J Pharmaceut 2009; 371(1-2): 106-113.

15. Nix D, De Vito J, Schentag J. Liquid-chromatographic determination of ciprofloxacin in serum and urine. Clin. Chem. 1985; 31: 684-686.

16. Montgomery MJ, Beringer PM, Aminmanizani A, Louie SG, Shapiro BJ, Jelliffe R, Gill MA. Population Pharmacokinetics and Use of Monte Carlo Simulation To Evaluate Currently Recommended Dosing Regimens of Ciprofloxacin in Adult Patients with Cystic Fibrosis. Antimicrob Agents Chemohter 2001; 45: 3468-73.

17. Kim YG, Kim HJ, Kwon JW, Kim WB, Lee MG. Bioequivalence of clarithromycin tablet formulations assessed in Korean males. Int J Clin Pharmacol Thera 2001; 39: 356-61.

18. Payen $S$, Serreau R, Munck A, Aujard $Y$, Aigrain $Y$, Bressolle F, Jacqz-Aigrain E. Population Pharmacokinetics of Ciprofloxacin in Pediatric and Adolescent Patients with Acute Infections. Antimicrob Agents Chemother 2003; 47: 3170-78.

19. Khan MK, Khan MF. Assessment of bioequivalence of ciprofloxacin in healthy male subjects using HPLC. Pak J Pharm Sci. 2008; 21: 299-306.

20. Khan MK, Khan MF, Khan H, Mustafa G. Bioavailability of ciprofloxacin tablets in humans and its correlation with the dissolution rates. Pak J Pharm Sci. 2009 Jul;22(3):329-34.

21. Forrest $A$, Nix $D E$, Ballow $C H$, Goss TF, Birmingham $M C$, Schentag JJ. Pharmacodynamics of intravenous ciprofloxacin in seriously ill patients. Antimicrob Agents Chemother 1993; 37:1073-81.

22. Shah A, Lettieri J, Blum R, Millikin S, Sica D, Heller AH. Pharmacokinetics of intravenous ciprofloxacin in normal and renally impaired subjects. J Antimicrob Chemother. 1996; 38: 103-16.

23. Lubasch A, Keller I, Borner K, Koeppe P, Lode H. Comparative Pharmacokinetics of Ciprofloxacin, Gatifloxacin, Grepafloxacin, Levofloxacin, Trovafloxacin, and Moxifloxacin after Single Oral Administration in Healthy. Antimicrob Agents Chemother 2000; 44: 2600-03.

24. Varela JE, Cohn SM, Brown M, Ward G, Namias N, Spalding PB. Pharmacokinetic and burn Escher penetration of intravenous ciprofloxacin in patients with major thermal injuries. J Animicrob Chemother 2000; 45: 337.42.

25. Shah A, Lettieri J, Blum R, Millikin S, Sica D, Heller AH. Pharmacokinetics of intravenous ciprofloxacin in normal and renally impaired subjects. J Antimicrob Chemother 1996; 38: 103-16.

26. Padol S, Yuan YH, Thabane M, Padol IT, Hunt RH. The effect of CYP2C19 polymorphisms on $\mathrm{H}$. pylori eradication rate in dual and triple fist-line PPI therapies: a meta-analysis. Am J Gastoenterol 2006; 101: 1467-75.

27. Horn J. Review article: Relationship between the metabolism and efficacy of proton pump inhibitor-focus on rabeprazole. Aliment Pharmacol Ther 2004; 20: 11-9.
28.

Chowdhury RZ, Islam MS, Rahman MS. Pharmacokinetic Parameters of Amoxicillin in Bangladeshi Volunteers: a Preliminary Evaluation. Bangladesh J Physiol Pharmacol 2010: 23: $1-9$.

29. Crump B, Wise R, Dent J. Pharmacokinetics and tissue penetration of ciprofloxacin. Antimicrob Agents Chemother 1983; 24: 784-6.

30. Davis RL, Koup JR, Williams-Warren J, Weber A, Smith AL. Pharmacokinetics of three oral formulations of ciprofloxacin. Antimicrob Agents Chemother 1985; 28: 74-7.

31. Ledergerber B, Bettex JD, Joos B, Flepp M, Luthy R. Effect of standard breakfast on drug absorption and multipledose pharmacokinetics of ciprofloxacin. Antimicrob Agents Chemother 1985; 27: 350-52.

32. Tartaglione TA, Raffalovich AC, Poynor WJ, Espinel Ingroff A, Kerkering TM. Pharmacokinetics and tolerance of ciprofloxacin after sequential increasing oral doses. Antimicrob Agents Chemother 1986; 29: 62-6.

33. Vance Bryan K, Guay DR, Rotschafer JC. Clinical pharmacokinetics of ciprofloxacin. Clinical Pharmacokinetics 1990; 19: 434-61.

34. Guay DR, Awni WM, Peterson PK, Obaid S, Stein D, Breitenbucher R. et al. Single and multiple dose pharmacokinetics of oral ciprofloxacin in elderly patients. Int J Clin Pharma Therapy Toxicol 1988; 26: 279-84.

35. Forrest A, Ballow CH, Nix DE, Birmingham MC, Schentag J]. Development of a Population Pharmacokinetic Model and Optimal Sampling Strategies for Intravenous Ciprofloxacin. Antimicrob. Agents Chemother. 1993; 37:1065-72. 